
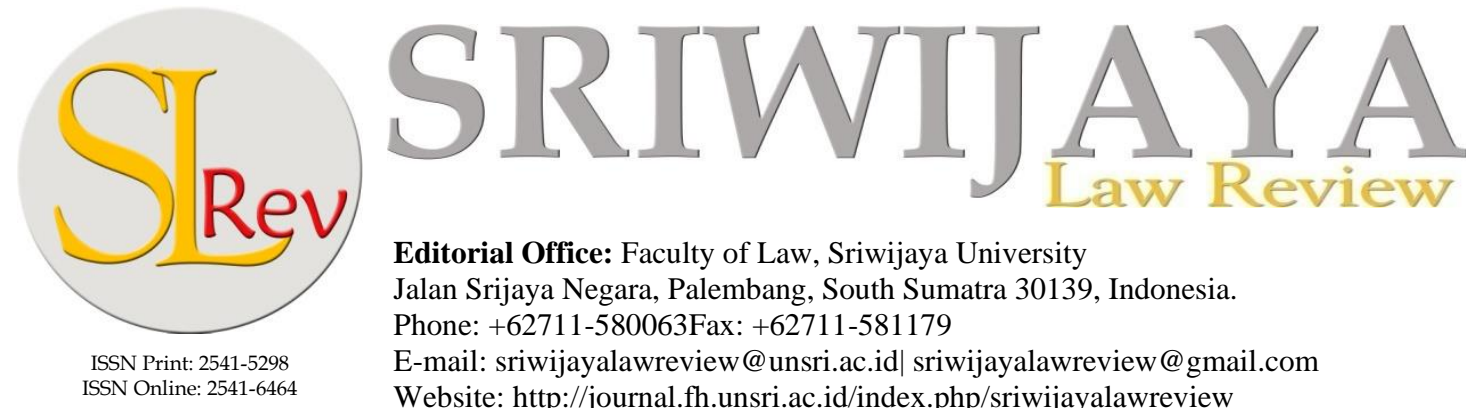

Editorial Office: Faculty of Law, Sriwijaya University

Jalan Srijaya Negara, Palembang, South Sumatra 30139, Indonesia.

Phone: +62711-580063Fax: +62711-581179

E-mail: sriwijayalawreview@unsri.ac.id| sriwijayalawreview@gmail.com

Website: http://journal.fh.unsri.ac.id/index.php/sriwijayalawreview

\title{
Law Enforcement Against Unreported Fishing: What Does Beyond the Catch Record?
}

\author{
Rachma Indriyani, ${ }^{a^{*}}$ Asmar Abdul Rahim, ${ }^{\mathrm{b}}$ and Ruzita Azmi ${ }^{\mathrm{b}}$ \\ a School of Law, Universiti Utara Malaysia, Malaysia \& Faculty of Law, Universitas Sebelas Maret, Indonesia. \\ Corresponding author Rachma Indriyani, email: rachma.indriey@gmail.com \\ b School of Law, Universiti Utara Malaysia, Malaysia.
}

\begin{tabular}{|c|c|}
\hline Article & Abstract \\
\hline $\begin{array}{l}\text { Article History } \\
\text { Received: Jan 19, 2021; } \\
\text { Reviewed: Des 17, 2021; } \\
\text { Accepted: Jan 30, 2022; } \\
\text { Published: Jan 31, } 2022 \text {. }\end{array}$ & $\begin{array}{l}\text { Transparency is significant in highly migratory fisheries. The reliability of } \\
\text { the catch data is essential for decisions of internationally agreed targets. } \\
\text { Nevertheless, the data accuracy will much depend on each state's } \\
\text { performance. Focusing on unreported catches of migratory fish, this study } \\
\text { highlights the Thunnus Macoyyi (Southern Bluefin Tuna) fishing in } \\
\text { Indonesia, as this fish species had experienced for being the limelight of } \\
\text { unreported fishing allegations. The main objective is to reveal what are the } \\
\text { difficulties that Indonesia is facing on its responsibility to maintain the } \\
\text { accuracy of the catch record. Accordingly, the study examines two points by } \\
\text { applying the pure legal method and doctrinal approach. Firstly, the } \\
\text { international legal framework towards unreported fishing by analysing three } \\
\text { main instruments such as the UNCLOS 1982, the UNFSA 1995, and the } \\
\text { CCSBT policies. Secondly, it examines Indonesia law enforcement as a } \\
\text { State party of regional fisheries organisation. It argues that the international } \\
\text { authority could not be completely extended to a State's domestic fishing } \\
\text { area. Thus, it gives more discretion to the national law to enforce } \\
\text { compliance. Lesson learned from the case study of Indonesia's southern } \\
\text { bluefin tuna contributes to unreported fishing literature and allows us to } \\
\text { expose the legal gap remained in managing highly migratory fish stocks. }\end{array}$ \\
\hline
\end{tabular}

(C)2022; This is an Open Acces Research distributed under the term of the Creative Commons Attribution License (https://Creativecommons.org/licences/by/4.0), which permits unrestricted use, distribution, and reproduction in any medium, provided the original works is properly cited.

\section{INTRODUCTION}

Reliable fisheries data is significant not only in relation to traceability but also for maintaining the integrity of related States, particularly in order to ensure sustainable fishing practices. The compliance of documents is essential also in international trade when the fish catch enters the market chain. ${ }^{1}$ State's compliance and adherence in managing resource use within their

Al-Amaren et al., "The Fraud Rules in the Letter of Credit under Jordanian Legal System," Sriwijaya Law Review 5, no. 2 (2021). 
jurisdiction should be described properly in the transparent report that may further impact international fisheries. As the fish stocks assessment and the marine environmental impact need fishery-dependent data collection, ${ }^{2}$ Accuracy information on fishing activity is valuable. The essence of data accuracy is stated by S.J. Kennelly and Borges.L as follows:" "As the accuracy of the scientific advice is directly related to the reliability of the original basic data, it is not only desirable for all countries to collect the necessary information but also their moral responsibility."

Some fish are managed under an international or regional agreement that States have signed up to. Since then, every member state has been obliged to monitor and be responsible for their fishing vessels conducting activities following the Regional Fisheries Management Organization (RFMO) regulation and indicate transparency and openness of their participation in relation to information sharing and disclosure. ${ }^{4}$ In practice, fishers behaviour is such a dominant influence on the process of catch data collection. ${ }^{5}$ It is noted from Rahmadi Sunoko and Hsiang-Wen Huang ${ }^{6}$, total of 355 Indonesian fishing vessels were included in Illegal Unreported Unregulated (IUU) fishing vessel list by some RFMOs. Both by the Commission for the Conservation of Southern Bluefin Tuna (CCSBT) and the International Commission for the Conservation of Atlantic Tuna.

Thunnus Macoyyi (Southern Bluefin Tuna) is a migratory fish which the management is under the RFMO rules, CCSBT, throughout distribution to its member States as national allocations. As one of the most expensive tuna, the species have experienced several international legal cases. The decisions significantly influence best practices on international fisheries law development. A very substantial matter concerning continuous over-catches of SBT since the early $1990 \mathrm{~s}^{7}$ indicates a lesson to learn how enforcement measures have not shown such tangible impact. An international investigation conducted by Australian officials in 2006 revealed that "Japanese long-liners SBT catches have exceeded officially reported catches in a significant proportion that the large unreported over-catches of SBT may have resulted in the misreporting of catches of other tuna species and/or misreporting of the location of fishing effort." ${ }^{8}$ It could be argued that among violations towards SBT fishing, unreported catches is a significant issue CCSBT has been dealt with.

The nature of SBT as a highly migratory fish that travels from one state's marine territory to high seas is a severe challenge for law enforcement. This does not deny that the more remote

2 Aloysius TM Van Helmond et al., "Electronic Monitoring in Fisheries: Lessons from Global Experiences and Future Opportunities," Fish and Fisheries 21, no. 1 (2020): 162-89.

3 S.J.Kennelly \& Borges, L. (eds.). Proceedings of the 9th International Fisheries Observer and Monitoring Conference, Vigo, Spainaa. ISBN: 978-0- 9924930-7-3.(2018).

4 Ruth A. Davis and Quentin Hanich, "Transparency in Fisheries Conservation and Management Measures," Marine Policy xxx, no. xxxx (2020), https://doi.org/10.1016/j.marpol.2020.104088.

5 Merrill B. Rudd and Trevor A. Branch, "Does Unreported Catch Lead to Overfishing?," Fish and Fisheries 18, no. 2 (2017).

6 Rahmadi Sunoko and Hsiang-Wen Huang, "Indonesia Tuna Fisheries Development and Future Strategy," Marine Policy 43, no. 175 (2014).

7 Tom Polacheck, "Considerations of Implications of Large Unreported Catches of Southern," CSIRO Marine and Atmospheric Research, Hobart, Tas 1 (2008).

8 Andrew Darby and Penelope Debelle, "Bluefin Tuna Scandal: Japan's Back Door Revealed, Sydney Morning Herald,” 2006, https:/www.smh.com.au/world/bluefin-tuna-scandal-japans-back-door-revealed-20060821gdo7vz.html . 
the fishing area, the weaker enforcement exists, creating the possibility to question the reliable catch report and other related fisheries data. Considering this broader context is essential that scientific fisheries data should be integrated with law and policy considerations to reach the fisheries management and conservation goals. The combination between rules and the institutional capacity defines whether the fisheries governance will be effective.

\section{RESEARCH METHODS}

The methodology used is pure legal research that adopted the doctrinal legal research or library-based approach. The fact that stability and certainty of law are desirable goals and social values to be pursued makes doctrinal research of primary concern. The doctrinal legal research intends to verify the case through legal reasoning or rational deduction. ${ }^{9}$ The researchers in this study look at the unreported fishing catch through SBT fisheries activity in Indonesia.

\section{ANALYSIS AND DISCUSSION}

\section{What the Law of the Sea Says}

\section{International Obligation to Maintain Accurate Catch Record in the UNCLOS 1982}

The primary purpose of the catch record is for the conservation and management of resources. To certain RFMOs, fisheries data is essential in negotiations regarding access to exclusive economic zone (EEZ) based on catch history. ${ }^{10}$ Further, the information will be useful to determine the stock status in a particular area of a coastal State. The relevant provision which deals with the conservation measures is set out in Article 61(5) of the United Nations Convention on the Law of the Sea (UNCLOS) 1982 as follow:

\footnotetext{
"The coastal State, taking into account available scientific information, catch and fishing effort statistics, and other data relevant to the conservation of fish stocks shall be contributed and exchanged on a regular basis through competent international organisations, whether sub-regional, regional or global, where appropriate and with participation by all States concerned, including States whose nationals are allowed to fish in the exclusive economic zone."
}

It will be apparent from the provision above that the LOSC 1982 does not provide any systematic reference to the data collection of "best scientific evidence" within the EEZ area of a coastal State. However, the only single approach expressly mentioned in the provision is cooperation through competent international or regional organisations. Thus, aside from exchanging available information, there is no primary responsibility for a coastal State, under the LOSC 1982, regarding data collection in the EEZ area.

Further in Article 62(4)(e), there will be a possibility for coastal States to impose certain obligations towards "nationals of other States fishing in the EEZ to specify the information required of fishing vessels, including catch and effort statistics and vessel position reports". According to this article, it can be assumed that the obligation to maintain the catch record in EEZ area might be subject to either coastal State or flag State (foreign fishing vessel).

Rather than biology science, literature in the view of legal aspects of fisheries data is not

9 K Vibhute and F Aynalem, "Legal Research Methods. Teaching Material," 2009.

10 Tom Polacheck, “Assessment of IUU Fishing for Southern Bluefin Tuna,” Marine Policy 36, no. 5 (2012): 1150-65. 
very much available. Regarding where the responsibility lies in providing information of catch record, one question might arise concerning how to synchronise the data collection between the coastal and the flag State. A brief analysis provided by Edeson ${ }^{11}$ had highlighted the issue "nationality of catches", which have determined catch belonging for two purposes, namely national law and statistical purposes. Under national law, the fish caught within an EEZ shall belong to the coastal state even though caught by a foreign fishing vessel. Meanwhile, information collected by flag States is better to recognise for statistical purposes. In other words, aside from the need to provide the catch information, "the UNCLOS 1982 is silent on who should provide the relevant information".

Uncertainty in the reported catches would imply unreported fishing catches, including misreported and under-reported catch. In addition to this, the obligation to provide specific information concerning catch and effort statistics in the UNCLOS 1982 does not further explain any details of the fishing vessel's criteria. The unreported fishing definition, thus, is not recognised in this convention.

\section{The UNFSA 1995}

While referring to another international law instrument such as the United Nations Fish Stock Agreement (UNFSA) 1995, based on this law agreement, every state has the right to perform "various enforcement roles such as Flag State, ${ }^{12}$ Inspecting state, ${ }^{13}$ and the Coastal States or Port State ${ }^{14}$

against any activity contrary to the conservation measures ${ }^{15}$ and vessel committed a serious violation". ${ }^{16}$ Nevertheless, this instrument has a specific limit of the implementation area, as stated by Article 3, the UNFSA 1995 applies in areas beyond national jurisdiction only. If the enforcement power extends to national areas of a State, the UNFSA 1995 can not be deemed a robust legal base. ${ }^{17}$

In respect of the obligation towards data collection, the instrument underlined the essence of inter-State, among coastal and flag States, cooperation in collecting and exchanging fisheries data. Article 7 presents a clear obligation, especially to the flag State as elaborated as follows: "Data collected by flag States must be shared with other flag States and relevant coastal States through appropriate sub-regional or regional fisheries management organisations or

11 W.R Edeson, "Legal Aspects of Data Collection of Fisheries Data," FAO Fisheries Circular 9, no. 953 (1999).

12 Article 19 of UNFSA 1995: "A State shall ensure compliance by vessels flying its flag"

13 Article 21 section 1 of UNFSA 1995: "In any high seas area covered by a subregional or regional fisheries management organisation or arrangement, a State Party which is a member of such organisation or a participant in such arrangement may, through its duly authorised inspectors, board and inspect fishing vessels flying the flag of another State Party to this Agreement, whether or not such State Party is also a member of the organisation or a participant in the arrangement, to ensure compliance with conservation and management measures for straddling fish stocks and highly migratory fish stocks established by that organisation or arrangement"

14 Article 23 section 1 of UNFSA1995 : "A port State has the right and the duty to take measures, under international law, to promote the effectiveness of subregional, regional and global conservation and management measures. When taking such measures, a port State shall not discriminate in form or fact against the vessels of any State."

15 Article 21 section 5 of UNFSA 1995.

16 Article 21 section 8 of UNFSA 1995.

17 Karen L Smith, "Highly Migratory Fish Species : Can International and Domestic Law Save the North Atlantic Swordfish?," Western New England Law Review 21, no. 1 (1999): 42. 
arrangements."

Further, the provision in Article 14(1)(b and (c) are required flag States to ensure the data are collected in sufficient detail and take necessary action to verify the data accuracy. Equally, in the area beyond national jurisdiction, the high seas, the duties of the flag State regarding the collection and exchange of scientific, technical and statistical data have been more pronounced in the UNFSA 1995 in Article 18 (3)(e) "requirements for recording and timely reporting of vessel position, catch of target and non-target species, fishing effort and other relevant fisheries data in accordance with sub-regional, regional and global standards for the collection of such data". However, aside from emphasising the flag State duty, this law instrument does not divine the possibility of unreported data or what threshold should be acknowledged to classify the data is insufficient.

In circumstances where the need for the legality of fisheries data is not expressly stated, there would be another role by state to monitor all fishing vessels that wish to land their catch, namely port State. As the last stop, the authority at the port will do validation and verification of catches. ${ }^{18}$ According to Article 23, it is recognised that a port is part of the internal water of coastal State territory so that state have absolute sovereignty with respect to:

"Deny port access to vessels registered in other States; prohibit vessels registered in other States from landing or transshipping fish in its ports; require vessels seeking port access to provide information as to their identity and activities including fishing gear and catch onboard fishing vessels; and inspect vessels that are voluntarily in one of its port."

From the provision, it can be seen a port State constitutes the final defence in investigating and detecting any violation derived from fishing vessel activities where Illegal, Unreported and Unregulated (IUU) fishing might occur. Inaccurate verification at the port will impact IUU products obtain official validation from coastal, port, and flag State that the product is legal. Further, it will not be easy to trace the legality of fishery products once they have been added to the supply chain. ${ }^{19}$

Nevertheless, the effective implementation of the UNFSA 1995 relies on each member State to perform the enforcement mechanism to ensure compliance and take further investigation and punitive action. ${ }^{20}$ Restrictions and limitations provided by law and regulatory provisions under the state's national law could constrain the release of information. Therefore, the national Law of either the flag or coastal State that enables them to provide information to the international forum is crucial. ${ }^{21}$

\section{Unreported Fishing Components}

In pursuant to the International Plan of Action to Prevent, Deter and Eliminate Illegal, Unreported and Unregulated Fishing (IPOA-IUU) paragraph 3.2, the nature of the scope of unreported fishing refers to fishing activities:

18 Gilles Hosch and Francisco Blaha, Seafood Traceability for Fisheries Compliance: Country-Level Support for Catch Documentation Schemes, FAO Fisheries and Aquaculture Technical Paper 619, 2017, http://www.fao.org/3/a-i8183e.pdf.

19 Hosch and Blaha.

20 Smith, "Highly Migratory Fish Species: Can International and Domestic Law Save the North Atlantic Swordfish?"

21 Edeson, "Legal Aspects of Data Collection of Fisheries Data." 
"3.2.1 which have not been reported, or have been misreported, to the relevant national authority, in contravention of national laws and regulations; or 3.2.2 undertaken in the area of competence of a relevant regional fisheries management organisation which have not been reported or have been misreported, in contravention of the reporting procedures of that organisation."

The definition provided by IPOA-IUU covers such a broad range of areas from unreported fishing from national territory to the area beyond national jurisdiction (Regional Organization area). Further, there is a certain degree of legal nuances and related terms not covered by IPOA provisions, particularly regarding the landing process. ${ }^{22}$ Moreover, while it is not merely about unloading fish catches at the port, fishing vessels could conduct unreported transhipment before they reach the port authority. A report revealed by The Maritime Executive ${ }^{23}$ concerning significant gaps in reporting, monitoring and data sharing "that only 25 carrier vessels reported high seas transshipments to the Western and Central Pacific Fisheries Commission's (WCPFC) secretariat in 2016 - but at least five times as many authorised carrier vessels potentially transshipped in port or at sea in WCPFC waters in 2016." It is then known that many fishing vessels managed transhipment at sea more than it was reported to the WCPFC authority, affecting the data accuracy concerning fish stock assessments. Inaccurate assessment will result in such biased data of fish population that may lead to increased fish harvest limits than the actual fish stock. ${ }^{24}$

Uncertainties in the reported catch data are likely the main component of unreported fishing. In RFMO practices, Makoto Peter Miyake ${ }^{25}$ compiled classification of a number of backgrounds in which these uncertainties shall occur: i) fish caught by non-RFMO authorised vessels; Terje L $\varnothing$ bach $^{26}$ added that the total allowable catch to fish in RFMO area is only given to vessels, Contracting Parties/ Cooperating non-Contracting Parties and/or fishing entities, have been registered so that they will be authorised; ii) unreported catches by small-scale fisheries including take home catches, same point of view by Pramod. G; ${ }^{27}$ according to an argument by Juan José Alava, ${ }^{28}$ the expansion of small-scale fisheries fleet has increasingly reached further distances from the shore, enabling them to grab non-target species (by-catch). However, most of these small-scale vessels are not registered in RFMO and do not hold specific quota allocation; iii) the absence of discarding report have a massive impact as stated

22 Pramod Ganapathiraju. "Illegal and unreported fishing: global analysis of incentives and a case study estimating illegal and unreported catches from India" (Unpublished doctoral dissertation). University of British Columbia, Canada. (2012).

23 The Maritime Executive, "Tuna Transshipment Management Compromised," 2019, https://www.maritimeexecutive.com/article/tuna-transshipment-management-compromised.

24 Metuzals. K, Wernerheim, C., Haedrich, R., Copes, P. and Murrin, A. "Data Fouling in Newfound-land's Marine Fisheries. Making and Moving Knowledge: Interdisciplinary and Community-based Research in a World on the Edge". McGill-Queens University Press, Montreal, pp. 121-137 in Merrill B. Rudd and Trevor A. Branch. Does unreported catch lead to overfishing?. Fish and Fisheries 18, no. 2.3. (2017).

25 Makoto Peter Miyake et al., "Recent Developments in the Tuna Industry: Stocks, Fisheries, Management, Processing, Trade and Markets," Food and Agriculture Organization of the United Nations 11 (2010).

26 Terje Løbach et al., "Regional Fisheries Management Organizations and Advisory Bodies: Activities and Developments, 2000-2017," FAO Fisheries and Aquaculture Technical Paper 651 (2020): 1-112.

27 Pramod Ganapathiraju, "Illegal, Unreported and Unregulated Marine Fish Catches in the Indian Exclusive Economic Zone," Field Report, Policy and Ecosystem Restoration in Fisheries, Fisheries Centre, University of British Columbia, BC, Vancouver, Canada 30 (2010).

28 Juan José Alava et al., "Mitigating Cetacean Bycatch in Coastal Ecuador: Governance Challenges for SmallScale Fisheries," Marine Policy 110, no. 2 (2019). 
by Kelleher; ${ }^{29}$ there will be a possibility when fishing gear catches undesired organism then release it (live or dead) Dirk Zeller ${ }^{30}$ argued it is mostly due to having little or no market value or subject to quota restriction; iv) errors in weighing report at landing centres; v) errors in species identification; it sometimes represents the difficulties in classifying two different juvenile tuna ${ }^{31}$ that captured together but have different commercial value, where less expensive fish are sold as expensive species, or in another possibility, for example, SBT species was taken by vessels fishing legally outside of the SBT regulated fishing areas, but it is reported as other species; vi) unreported catches resulted from recreational fishers, including catches sold by fishers directly to tourist resorts and restaurants; vii) Fish caught from Exclusive Economic Zone (EEZ) of one country, then unloaded in another country to be reported as catches from high seas

Regarding SBT fishing mainly, CCSBT has defined some activities classified as IUU Fishing. In the provision of Resolution on Establishing a List of Vessels Presumed to have Carried Out Illegal, Unreported and Unregulated Fishing Activities For Southern Bluefin Tuna (SBT), IUU Fishing is that when a member State of cooperating non-Member are performing the following actions: a) "Harvested SBT and were not authorised by a Member or Cooperating Non-Member to fish for SBT", or; b) "Did not record and/or report their SBT catches or catchrelated data in accordance with CCSBT reporting requirements, or made false reports", or; c) "Used prohibited or non-compliant fishing gear in a way that undermines CCSBT conservation and management measures", or; d) "Transhipped with, or participated in joint operations such as re-supplying or re-fuelling vessels included in the CCSBT IUU Vessel List", or; e) "Harvested SBT in the waters under the national jurisdiction of the coastal State or entity without authorisation and/or committed a serious infringement of its laws and regulations directly related to the SBT fishery, without prejudice to the sovereign rights of the coastal State or entity to take measures against such vessels", or; f) "Engaged in fishing activities for SBT, including transhipping, re-supplying or re-fuelling, contrary to any other CCSBT conservation and management measures."

The duty to maintain official catch data is described in point $b$ above, which fishing nation must provide the accurate report including either catches and catch-related. While it is mentioned that false reports are classified as IUU fishing, it is possibly uneasy to determine whether one report submitted by one state is error-free.

\section{Indonesia's Southern Bluefin Tuna Case}

Tuna resources are essential for Indonesia fisheries as the country contains large marine waters and ecosystems with high biodiversity. ${ }^{32}$ Due to some tuna species being subject to international cooperation, Indonesia adopted international regulation to the domestic level concerning conservation measures for future sustainable development. As a matter of fact, tuna stocks in Indonesian waters are at knifepoint, which most tuna species threaten. According to

29 Kelleher K, Discards in the World's Marine Fisheries, an Update, Food and Agriculture Organization of the United Nations, 2005.

30 Dirk Zeller et al., "Global Marine Fisheries Discards: A Synthesis of Reconstructed Data," Fish and Fisheries 19, no. 1 (2018): 30-39.

31 Polacheck, "Considerations of Implications of Large Unreported Catches of Southern."

32 Sunoko and Huang, "Indonesia Tuna Fisheries Development and Future Strategy." 
the Minister of Marine Affairs and Fisheries Decree No. KEP.45/MEN/2011 on the Estimation of Fish Resources Potential in Indonesia's Fisheries Management Areas, the condition of tuna stock and exploitation rate in Indonesia is shown in Table 1 as follows:

Table 1. The Exploitation Rate of Tuna Stock in Indonesia

\begin{tabular}{lll}
\hline Stock & Scientific Name & Status \\
\hline Bigeye tuna & Thunnus obesus & has been over-exploited \\
Yellowfin tuna & Thunnus albacares & being fully exploited \\
Albacore & Thunnus alalunga & classified as fully exploited \\
Skipjack & Katsuwonus pelamis & classified as moderate \\
Southern Bluefin tuna & Thunnus maccoyii & Classified as overexploited \\
\hline
\end{tabular}

Source: Minister of Marine Affairs and Fisheries Decree No. KEP.45/MEN/2011

Aside from having higher economic value ${ }^{33}$ of five tuna species, Indonesian SBT (Thunnus maccoyii) is the only species classified as overexploited. Valid information of the current status of related tuna species is dully required to justify the allowable catch. The overexploited status seems an alarm for SBT fisheries to maintain the conservation plan to keep the fish stocks sustainable.

CCSBT determines a Total Allowable Catch (TAC) and distributes the amount of quota to every member State to catch the fish stocks either in high seas or EEZ. Through the quota mechanism, every member must catch not exceeding the allocated national quota for keeping the fish stocks sustained.

Between 2018 and 2020, the TAC of SBT stock assessed by CCSBT is 17.335 tons which Indonesia has 1.023 tons of the total TAC. Indonesia allocated the SBT quota to each company through tuna associations (ATLI, ASTUIN, ASPERTADU). Each company under associations must register all of their vessels on the CCSBT Record of Vessel Authorised to get authorisation to fish for SBT. In comparison to previous years, the quota allocation had been increased. However, it is discovered in Annual Report to the Compliance Committee and the Extended Commission CCSBT (2018) Indonesia was overcaught on its national SBT quota since the fishing year of 2011.

There should be two questions concerning the SBT national quota allocation. Firstly, whether the increase in quota has been adjusted to the status of SBT stock, suppose, refer to the description in Table 1, the increase of SBT quota seems to contrast to the overexploited status. Second, questioning the sources of an excess catch of Indonesia SBT fishing.

In the 2013 Report of the Twentieth Annual Meeting of the Commission, Indonesia delivered the issue on SBT fishing that many small-scale fishers are involved despite the SBT caught by their vessel being by-catch. In other words, Widiarso argued ${ }^{34}$ that those small fisherman caught SBT unintentionally while catching certain target species and target sizes of fish. The justification stated by Indonesia states as follow:

33 Fatur Rochman, Maya Agustina, and Gussasta Levi Arnenda, "Total Allowable Catch of Indonesian Southern Bluefin Tuna Thunnus Maccoyii and Its Potential Resources in The Indian Ocean," E3S Web of Conferences 147 (2020): 02013.

34 Antonius Widiarso, "Implementasi Rezim Commission for The Conservation Of Southern Bluefin Tuna (CCSBT) Di Indonesia: Ketidakpatuhan Total Allowable Catch Southern Bluefin Tuna," Journal of International Relations 4, no. 2 (2018): 225-33. 


\begin{abstract}
"But after implementing the quota approach within 5 (five) years, we have had some difficulties controlling the annual catch limit based on the current reserved quota, due to the existence of artisanal tuna long-liner or small scale fisheries, that are mainly fishing within Indonesia fisheries management zone. We could not prevent them from catching SBT since SBT is caught as unexpected by-catch. We also could not blame them or fine them from catching SBT since they do not intend to catch the fish, but other tunas as their main livelihood. Moreover, they have been involved in this artisanal tuna longline fisheries for some decades."
\end{abstract}

While, basically, there is no particular provision that small-scale fishing vessels should be included in the category of the authorised vessel for SBT fishing. CCSBT has issued the list of the authorised vessel for official reference. It is known from the record that Indonesia has registered 120 small-scale longline vessels. ${ }^{35}$ Regarding electronic monitoring system via VMS, it seems demanding job for the authority to monitor small-scale fishing vessels that do not install such equipment, as the regulation merely refers to VMS obligation for vessel >30 GT. After all, if those small-scale vessels are not counted in SBT quota recipient, there will be gaps regarding take-home catches and the fished quota allocation report. Thus, again, the data uncertainties or errors in reporting may lead to unreported fishing components. Considering that reliable catch data information is crucial for successful fisheries management. However, Dyhia Belhabib ${ }^{36}$ assumed the data collection is heavily dependent on fishery actors to be willing to share information.

\title{
The Law Enforcement
}

The enforcement term in the UNCLOS 1982 is described in Article 213 to Article 222. However, unless any damage resulted from pollution, none of these articles covers fishing activities specifically. With respect to fishing, Article 221(2) barely refer to measures to avoid pollution arising from maritime casualties in which the scope is "collision of vessels, stranding or other incidents of navigation, or other occurrences on board a vessel or external to it resulting in material damage or imminent threat of material damage to a vessel or cargo."

Instead of the legal origin of the catch and the degradation of fish stocks, the said articles are more emphasised the damage to the marine environment. It is then strengthened in Article 235 regarding the state's responsibility and liability for any harm resulting from marine environment pollution. ${ }^{37}$ The inadequate provisions in the international framework concerning unreported catch, which primarily refer to fishing operation under national area, can be seen as more discretion to the national Law of each State.

This section assumes monitoring measures and corrective actions are significant elements in conducting law enforcement against unreported fishing. In this context, the enforcement measures are considered into two situations: before landing (when the fishing activity is taking place) and the process immediately after landing.

35 Bram Setyadji and I Jatmiko, “Comparison of Indonesia Tuna Longline Fishing Performance Within And Outside Indonesia Exclusive Economic Zone (EEZ)," Indonesian Fisheries Research Journal 23, no. 1 (2017), https://doi.org/DOI: 10.15578/ifrj.23.1.2017.1-6.

36 Dyhia Belhabib et al., "Fisheries Catch Misreporting and Its Implications: The Case of Senegal," Fisheries Research 151 (2014): 1-11.

37 Zaki Mubarok. Illegal, unreported and unregulated fishing and transnational organised fisheries crimes: Perspectives of legal and policy measures of Indonesia (Unpublished doctoral dissertation). University of Wollongong, Australia. (2019). 


\section{Monitoring Measures}

Concerning Indonesia case on SBT fishing, it needs to review how the country has exercised its best possible efforts, particularly monitoring action. Compliance with the Conservation and Management Measures should be the foundation of sustainable fisheries. Indonesia has managed to implement logbooks, enumerators officers, Vessel Monitoring System and fisheries observers. Many aspects influence the practical implementation, but basically monitoring tool is the most crucial aspect for law enforcement.

Indonesia is persistent in supporting enforcement combating IUU fishing practices through utilising Vessel Monitoring System (VMS) Data to detect illegal activities. ${ }^{38}$ Based on Ministry Regulation No. 42 of 2015 on the Vessel Monitoring System, VMS are mandatory to all Indonesian fishing vessels more significant than 30 Gross Tonnage (GT). Moreover, the insufficient officer to operate the VMS centre is still an unfinished issue that will impact enforcement action. ${ }^{39}$ Therefore, the VMS utilisation should be incorporated with at-sea inspections to monitor compliance when the vessel is fishing.

It is stated in the 2018 Annual Report to CCSBT Compliance Committee that fisheries patrol is primarily conducted within the Indonesia territorial water, and this is not exclusively to SBT tuna fishing vessels. In addition to this concerning report document, there is no further explanation regarding actions and measures towards the authorised vessel requirements, including any sanction taken. The Fisheries Management Area (FMA) for SBT is located in FMA 573, which covers the Exclusive Economic Zone (EEZ) beyond territorial water. Further, the SBT catch rate outside EEZ was higher than within EEZ, demonstrating that fishing outside EEZ is more desirable. ${ }^{40}$ By identifying the fishing location regarding highly migratory species, the enforcement should be more focused on the concerned area.

Under international law, the Port States have the authority to monitor and inspect all fishing vessels as this is the entry point that all catches transit from the sea into the land. The quality of port monitoring will influence the capability to track IUU catches. ${ }^{41}$ Considering that the sea is such a large area and complicated to monitor, enforcement measures by port State, as Zaki Mubarok has mentioned, are more efficient to detect IUU catches before landing. As elaborated in Article 218 of the LOSC 1982 concerning enforcement by the Port States, it is port authority to supervise all fishery transactions, including inspecting, denying or prohibiting access to visiting fishing vessels, either domestic or foreign vessels, from landing or landing or prohibiting vessels transshipping fish in the port.

Enforcement at the port should examine the logbooks and collect other relevant information that at least covers the following elements: "the port, date and time of any inspection; the flag state of the vessel, and its identification; the name, nationality and qualifications of the master; authorisations for fishing and transhipments; type of fishing gear;

\footnotetext{
38 "26th Annual Meeting of the CCSBT," Cape Town, South Africa, 2019, https://www.ccsbt.org/en/content/26th-annual-meeting-ccsbt.

39 Sunoko and Huang, "Indonesia Tuna Fisheries Development and Future Strategy."

40 Setyadji and Jatmiko, "Comparison of Indonesia Tuna Longline Fishing Performance Within And Outside Indonesia Exclusive Economic Zone (EEZ).”

41 Hosch and Blaha, Seafood Traceability for Fisheries Compliance: Country-Level Support for Catch Documentation Schemes.
} 
catch onboard - origin, species, form and quantity, and catch to be landed/ retained on board; total catch landed and/or transhipped; and inspection findings". Once the result of inspections has been done, the report should be forwarded to the Flag State and related RFMO. In the end, no member State or cooperating non-member shall accept SBT catches that have not been validated. Port State is the last line of defence at this inspection stage to avoid IUU fish catches landing and being added to supply chains. Once IUU products have obtained official justification from Flag and Port State, it will be difficult to identify them again in the logistic network.

In respect of port inspection for SBT catches the only legally binding international law instrument reinforcing the role of Port State in addressing IUU fishing before entry into Port is Agreement on Port State Measures to Prevent, Deter, and Eliminate Illegal, Unreported, and Unregulated Fishing (PSMA). The process of validating and monitoring SBT in quantity follows the Catch Documentation Scheme (CDS) procedure as a critical element for port entry. Indonesia has signed and ratified this PSMA through Presidential Regulation No.43 of 2016. There are some designed ports for foreign fishing vessels that carry SBT to request entry into port. The following designed ports are Port of Nizam Zachman-Jakarta, Port of Bungus-West Sumatra, Port of Ambon-Maluku, Port of Bitung-North Sulawesi, and Port of PelabuhanratuWest Java. ${ }^{42}$ However, the system used for controlling and monitoring domestic landings of SBT is not explicitly provided. Assuming that SBT fishing only landed in Bali, the inspection for tuna species does on a random basis, not exclusively for SBT.

Tagging is an obligation to all SBT catches as the records information on individual fish is part of the CDS procedure to track trade and illegal fishing for SBT. Under the CDS, commercial fishers must have preliminary consideration about tagging, either they intend to fish for SBT species as the primary target or as by-catch. Catch Tagging Form is one document that must be included in the CCSBT CDS report. If one element of the document is found incomplete, the member State shall not validate the relevant form as it can result in such incorrect information. In Indonesia's national legal mechanism, the administrative sanction is applied to all fishing vessels that did not fulfil the logbook requirement. Failing to submit a fisheries logbook may result in the suspension of license for a maximum of one month. If the Captain fails to accomplish the related obligation during one month sanction period, the authority can revoke the license.

According to compliance report in 2019, the CCSBT indicated that in 2018 Indonesia did not apply tagging immediately after the fishers caught SBT at sea: "that at least 606 SBT caught by Indonesia recorded on 15 different CMFs, were not tagged at the time of kill, and in some cases could not have been tagged for up to 5 to 7 months after the time of kill."

In other words, Indonesian vessels only attach tags while just landing. The reason shows how initially, owners and captains of the vessels did not consider carrying tags before sailing because they reckoned SBT as by-catch. If an authorised vessel does not have sufficient tags onboard, this should be categorised as exceptional circumstances that the flag State is further required to provide clarification. Otherwise, it could be possible to expect attaching tags while landing to continue.

42 Indonesia Annual Report 2018. 
The validation process of catch data is expected to be accurate. Thus, all CCSBT's Member States are requested to place observers onboard carrier vessels. According to CCSBT Scientific Observer Program Standards in Compliance Policy Guideline 1, the minimum performance requires "the target observer coverage of $10 \%$ for catch and effort monitoring in each fishery". An interview with the authorised person at the Ministry of Marine Affairs and Fisheries of Indonesia on 28 January 2020 explained that this requirement is likely hard to implement for Indonesia since the observer coverage is still under the minimum coverage until recently. By doing so, the justification of SBT catches by Indonesian vessels may be argued as less verified since it did not provide an independent inspector on board. The presence of observers onboard may conduct various roles, either for enforcement or fisheries science. ${ }^{43}$ In this context, Indonesia is unlikely concerned with observer engagement, especially regarding highly migratory fish.

In addition, all member and non-member States who catch SBT are obliged to apply the Catch Documentation Scheme (CDS), which is used to verify the number of SBT that have been captured. Equally important, all SBT that have been caught must be tagged. In doing so, SBT documentation in Indonesia is conducted by a data validation officer to justify the fishing report. There are two locations for validator officer placement, namely Benoa Fishing Port, Bali and Nizam Zachman Fishing Port, Jakarta. ${ }^{44}$ In practice, it is known that there is another region where non-tagged SBT catches landed, namely Ratu Fishing Port in West Java and Cilacap Fishing Port in Central Java. Most of the fishing vessels in these two ports are relatively occupied by small-scale fishing vessel activities and do not exclusively target SBT. Even though nearly all of the catches are locally sold, it has been revealed there was an attempt to export individuals SBT to Japan without tagging. ${ }^{45}$ Since, official, there is no validator officer available in Ratu Fishing Port and Cilacap Fishing Port and no tagging mechanism implemented either. Therefore, it can be assumed that SBT catches in these two ports are classified as unreported fishing.

Moreover, the undetected SBT fishing by small-scale fishers revealed a gap in authorisation towards fishing vessels to catch SBT. In Indonesian practice, a fishing vessel must join an association and register vessel to CCSBT. The registered vessel is authorised to gain an amount of quota and catch the SBT. This provision is stated in CCSBT Resolution: "Fishing Vessels not entered into the record are deemed not to be authorised to fish for, retain on board, transship or land SBT regardless of their size". Considering that small-scale fishers in Indonesia catch SBT as by-catch and the absence of law and regulation on how to treat that bycatch, the SBT catch caught by small-scale fishers can possibly be recognised as "illegal and unreported fishing".

\section{Corrective Actions}

Especially for highly migratory fish stocks such as SBT, the obligation of Flag State to impose

\footnotetext{
43 Read D.Porter, "Fisheries Observers as Enforcement Assets: Lessons from the North Pacific," Marine Policy 34, no. 3 (2010): 583-89.

44 The Decision of Director General of Capture Fishery No.2/KEP-DJPT/2013 concerning Validator Officer of Catch Documentation Scheme for Southern Bluefin Tuna

45 The CCSBT Annual Review (2011).
} 
relevant fisheries data including vessel position, catch of target and non-target species, fishing effort, and transhipment are mandatory as stated in Article 18(3) of the UNFSA 1995. Article 21 stipulates that "failing to maintain accurate records of catch and catch-related data, as required by the RFMO arrangement, or serious misreporting of catch, shall be considered as a serious violation". The flag State should take further action towards a serious violation called outstanding sanctions. On the other hand, none of UNCLOS provisions elaborates the standard for the outstanding sanctions terminology. ${ }^{46}$

Even though the FMA 573 is mostly located in Indonesia's EEZ, the fish stocks, southern bluefin tuna, are considered highly migratory fish that the management is under the international arrangement. Therefore, the enforcement towards a vessel operating in the FMA 573 can use the analogy of the simple link principle in Article 91 of the UNCLOS 1982. It is shown the obligation for every State "to apply its jurisdiction and control effectively in administrative, technical and social matters over ships flying its flag". When a vessel flying its flag has been found conducting Illegal Unreported Unregulated (IUU) Fishing, the Flag State has to take necessary investigation and/or any action to remedy the situation. A similar perspective is expressed on the Advisory Opinion of the Seabed Disputes Chamber. It stated that this is an obligation "to deploy adequate means, to exercise best possible efforts, to do the utmost" to prevent Illegal Unreported Unregulated (IUU) fishing by ships flying its flag. ${ }^{47}$

In pursuant to Advisory Opinion by International Tribunal for the Law of the Sea on the Request submitted to the Tribunal by the Sub-Regional Fisheries Commission (SRFC), it has clarified whose own liability against IUU fishing:

"The liability of the flag State does not arise from a failure of vessels flying its flag to comply with the laws and regulations of the SRFC Member States concerning IUU fishing activities in their exclusive economic zones. The liability of the flag State arises from its failure to comply with its due diligence obligations concerning IUU fishing activities conducted by vessels flying its flag.."

That is to say, if the flag State has applied due diligence obligations to prevent all vessels flying its flag involved in IUU fishing, the liability could not be charged to the flag State. In defining what should include in due diligence obligation, The Seabed Disputes Chamber, in ITLOS Advisory Opinion ${ }^{48}$ referred to the following clarification provided by the International Court of Justice in the Pulp Mills on the River Uruguay case, that is underlined "enforcement and administrative control" as elaborated as follow:

"It is an obligation which entails not only the adoption of appropriate rules and measures but also a
certain level of vigilance in their enforcement and the exercise of administrative control applicable to
public and private operators, such as the monitoring of activities undertaken by such operators, to
safeguard the rights of the other party. The responsibility of a party to the 1975 Statute would therefore
be engaged if it was shown that it had failed to act diligently and thus take all appropriate measures to
enforce its relevant regulations on a public or private operator under its jurisdiction."

Indonesia issue on unreported fishing is a unique case that the primary reason delivered in the annual report is small-scale fishers involvement. By contrast, Indonesian national law and regulations have privileged small-scale fishers in fishing activities. Article 7(3) of Fisheries Act

\footnotetext{
46 H. Doremus, "Why International Catch Shares Won't Save Ocean Biodiversity," Mich. J.Envtl. \& Admin. L 2, no. 385 (2012).

47 ITLOS Report (2011).

48 ITLOS Advisory Opinion (2011).
} 
No 45 of 2009 mentions that the exception includes catching report obligation and the monitoring system. At the same time, according to Article $100 \mathrm{C}$, small scale fishers are potentially punished if they breach the obligation. The contradiction between these two articles could potentially create a gap in the possibility of giving the non-compliance label to smallscale fishers. The law and regulation do not clearly describe small-scale fishers who do activities within national fishing zones.

The obscure enforcement action towards unreported fishing and the distribution of the SBT quota will also influence the data accuracy. The tagging issue to SBT catches committed by Indonesia has demonstrated that the tuna associations are facing difficulties monitoring the tag used by fishers. ${ }^{49}$ In a situation where associations do not perform sufficient monitoring action, the inaccuracy will possibly appear between the catch record from the government and the tuna association. However, sanction or punishment is not applicable yet against such violation acts. Regardless of having the discretion to apply its enforcement towards its national fishing vessels, the uncontrolled and the excuse of tagging obligation can be the gap for Indonesia to enforce the law due to the existing law and policy are still lack of adopting the minimum performance to meet CCSBT compliance.

Aside from the difficulties in monitoring the small scale fishers catching SBT, the enforcement is flawed due to the deficiency of inspection mechanisms towards SBT fishing in high seas. It will open the gap for the state in losing track if national fishing vessels land the SBT in other countries (foreign ports) or the IUU catches from high seas landing in domestic port. In the end, no member State or cooperating non-member shall accept SBT catches that have not been validated. Port State is the last line of defence at this inspection stage to avoid IUU fish catches landing and being added to supply chains. Once IUU products have obtained official justification from Flag and Port State, it will be difficult to identify them again in the logistic network.

\section{CONCLUSION}

From Indonesia's southern bluefin tuna case, it can be seen how this fish species has been caught as a non-target catch by a small-scale fishing vessel. Even so, the effect of this practice, as elaborated in the CCSBT annual report documents, is consequential unreported fishing. The catch tagging problem, the issue of authorisation to fish, lack of verification process at the port are some of the crucial points that will influence the reliability of fisheries data. It can be a gap for Indonesia to enforce the law because the existing law and policy are still lacking in adopting the minimum performance to meet CCSBT compliance. Considering that failing to maintain the accuracy of fisheries reports can be identified as "serious violation", there should be severe enforcement measures and investigation as a member State committed to managing highly migratory fish resources. The accurate report will determine the accurate fish stocks assessment, and it will impact the goal of sustainable fisheries. In addition, as southern bluefin tuna has a migratory nature, Indonesia needs to enhance monitoring at sea and extent the scope of monitoring area beyond territorial water. Therefore, the extraterritorial nature of enforcement should be acknowledged in Indonesian law. While the electronic system nowadays

49 Novia Tri Rahmawati, "Pengelolaan Kuota Penangkapan Tuna Sirip Biru Selatan Di Indonesia," Institut Pertanian Bogor 50 (2014). 
is the most pillar for monitoring, this tool still needs regular inspection at sea to ensure compliance is on the card.

\section{REFERENCES}

Al-Amaren, Emad Mohammad, Che Thalbi Bt Md Ismail, and Mohd Zakhiri bin Md Norb. "The Fraud Rules in the Letter of Credit under Jordanian Legal System." Sriwijaya Law Review 5, no. 2 (2021).

Alava, Juan José, Bradley Tatar, María José Barragán, Cristina Castro, Patricia Rosero, Judith Denkinger, Pedro J. Jiménez, Raúl Carvajal, and Jorge Samaniego. "Mitigating Cetacean Bycatch in Coastal Ecuador: Governance Challenges for Small-Scale Fisheries.” Marine Policy 110, no. 2 (2019).

Belhabib, Dyhia, Viviane Koutob, Aliou Sall, Vicky WY Lam, and Daniel Pauly. "Fisheries Catch Misreporting and Its Implications: The Case of Senegal." Fisheries Research 151 (2014): 1-11.

Cape Town, South Africa. "26th Annual Meeting of the CCSBT," 2019. https://www.ccsbt.org/en/content/26th-annual-meeting-ccsbt.

Porter, Read D. "Fisheries Observers as Enforcement Assets: Lessons from the North Pacific." Marine Policy 34, no. 3 (2010): 583-89.

Darby, Andrew, and Penelope Debelle. "Bluefin Tuna Scandal: Japan's Back Door Revealed, Sydney Morning Herald," 2006. https:/www.smh.com.au/world/bluefin-tuna-scandaljapans-back-door-revealed-20060821-gdo7vz.html .

Davis, Ruth A., and Quentin Hanich. "Transparency in Fisheries Conservation and Management Measures." Marine Policy xxx, no. xxxx (2020). https://doi.org/10.1016/j.marpol.2020.104088.

Doremus, H. "Why International Catch Shares Won't Save Ocean Biodiversity." Mich. J.Envtl. \& Admin. L 2, no. 385 (2012).

Edeson, W.R. "Legal Aspects of Data Collection of Fisheries Data." FAO Fisheries Circular 9, no. 953 (1999).

Executive, The Maritime. "Tuna Transshipment Management Compromised," 2019. https://www.maritime-executive.com/article/tuna-transshipment-managementcompromised.

Ganapathiraju, Pramod. "Illegal , Unreported and Unregulated Marine Fish Catches in the Indian Exclusive Economic Zone." Field Report, Policy and Ecosystem Restoration in Fisheries, Fisheries Centre, University of British Columbia, BC, Vancouver, Canada 30 (2010).

Helmond, Aloysius TM Van, Lars O. Mortensen, Kristian S. Plet-Hansen, Clara Ulrich, Coby L. Needle, Daniel Oesterwind, Lotte Kindt-Larsen, and At Al. "Electronic Monitoring in Fisheries: Lessons from Global Experiences and Future Opportunities." Fish and Fisheries 21, no. 1 (2020): 162-89.

Hosch, Gilles, and Francisco Blaha. Seafood Traceability for Fisheries Compliance: CountryLevel Support for Catch Documentation Schemes. FAO Fisheries and Aquaculture Technical Paper 619, 2017. http://www.fao.org/3/a-i8183e.pdf. 
K, Kelleher. Discards in the World's Marine Fisheries, an Update. Food and Agriculture Organization of the United Nations, 2005.

Løbach, Terje, Matilda Petersson, Eliana Haberkon, and Piero Mannini. "Regional Fisheries Management Organizations and Advisory Bodies: Activities and Developments, 20002017." FAO Fisheries and Aquaculture Technical Paper 651 (2020): 1-112.

Miyake, Makoto Peter, Patrice Guillotreau, Chin-Hwa Sun, and Gakushi Ishimura. "Recent Developments in the Tuna Industry: Stocks, Fisheries, Management, Processing, Trade and Markets." Food and Agriculture Organization of the United Nations 11 (2010).

Polacheck, Tom. "Assessment of IUU Fishing for Southern Bluefin Tuna." Marine Policy 36, no. 5 (2012): 1150-65.

- "Considerations of Implications of Large Unreported Catches of Southern." CSIRO Marine and Atmospheric Research, Hobart, Tas 1 (2008).

Rahmawati, Novia Tri. "Pengelolaan Kuota Penangkapan Tuna Sirip Biru Selatan Di Indonesia." Institut Pertanian Bogor 50 (2014).

Rochman, Fatur, Maya Agustina, and Gussasta Levi Arnenda. "Total Allowable Catch of Indonesian Southern Bluefin Tuna Thunnus Maccoyii and Its Potential Resources in The Indian Ocean." E3S Web of Conferences 147 (2020): 02013.

Rudd, Merrill B., and Trevor A. Branch. "Does Unreported Catch Lead to Overfishing?" Fish and Fisheries 18, no. 2 (2017).

Setyadji, Bram, and I Jatmiko. "Comparison of Indonesia Tuna Longline Fishing Performance Within And Outside Indonesia Exclusive Economic Zone (EEZ)." Indonesian Fisheries Research Journal 23, no. 1 (2017). https://doi.org/DOI: 10.15578/ifrj.23.1.2017.1-6.

Smith, Karen L. "Highly Migratory Fish Species : Can International and Domestic Law Save the North Atlantic Swordfish?” Western New England Law Review 21, no. 1 (1999): 42.

Sunoko, Rahmadi, and Hsiang-Wen Huang. "Indonesia Tuna Fisheries Development and Future Strategy." Marine Policy 43, no. 175 (2014).

Vibhute, K, and F Aynalem. "Legal Research Methods. Teaching Material,” 2009.

Widiarso, Antonius. "Implementasi Rezim Commission for The Conservation Of Southern Bluefin Tuna (CCSBT) Di Indonesia: Ketidakpatuhan Total Allowable Catch Southern Bluefin Tuna." Journal of International Relations 4, no. 2 (2018): 225-33.

Zeller, Dirk, Tim Cashion, Maria Palomares, and Daniel Pauly. "Global Marine Fisheries Discards: A Synthesis of Reconstructed Data." Fish and Fisheries 19, no. 1 (2018): 3039. 